\title{
Pumpkin Fruit Flour as a Source for Food Enrichment in Dietary Fiber
}

\author{
Judita ČERNIAUSKIENË* Jurgita KULAITIENĖ, Honorata DANILČENKO, \\ Elvyra JARIENĖ, Edita JUKNEVIČIENÉ
}

\author{
Institute of Agriculture and Food Sciences, Aleksandras Stulginskis University, Studentu str. 11, LT-53361 Akademija, Kaunas distr., \\ Lithuania; judita.cerniauskiene@asu.lt ( ${ }^{*}$ corresponding author)
}

\begin{abstract}
It is believed that fiber-rich diet reduces the risk of certain cancers, coronary heart and other diseases. Dietary fiber (DF) is not only used for its nutritional properties, but also for its functional and technological properties. Thus, to supplement daily diet, dietary fiber should be incorporated into frequently consumed foods. Pumpkins are a good source of carotenoids, mineral salts, vitamins, and other bioactive substances, such as phenol compounds. Also the pumpkin flour could be used for food enriching as fiber supplement. In the study standard methods were applied to determine and compare the neutral dietary fiber (NDF), acid dietary fiber (ADF), acid detergent lignin (ADL) and water-soluble carbohydrates (WSC) contents in pumpkins fruits flour obtained from different species and cultivars. The results imply that pumpkin fruit flour should be recommended as the component suitable for food production with high content of DF. The fiber content in the pumpkin fruit flour depends on the cultivar. The maximum insoluble fiber content (NDF, ADF, ADL) was accumulated in C. maxima 'Kroshka' pumpkin flour: 26.50\%, 24.65\% and $14.35 \%$, respectively, and this cultivar is the most suitable one for enriching food with dietary fiber.
\end{abstract}

Keywords: acid dietary fiber, lignin, neutral dietary fiber, pumpkin fruit flour, water-soluble carbohydrates

\section{Introduction}

Dietary fiber is a group of food components that is resistant to hydrolysis by human digestive enzymes and is necessary for promoting good health (AACC Report, 2001). Although its health-promoting properties have been recognized for several decades, the dietary fiber itself has long been regarded as an indigestible ballast component of a edible plant (Jenkins et al., 1998; Jiménez-Escrig and Sánchez-Muniz, 2000).

Many studies on dietary fiber have revealed that the components show the ability to bind numerous substances, including cholesterol and gastric juice (Jenkins et al., 1998; Jiménez-Escrig and Sánchez-Muniz, 2000; Sangnark and Noomhorm, 2003; Mai et al. 2003; Correa Lima and Gomes da Silva, 2005; Rodrígez et al., 2006). Also, dietary fiber plays an important role in the prevention and treatment of diabetes, obesity, atherosclerosis, heart diseases, colon cancer and colorectal cancer (Wang et al., 2002; Ferguson and Harris, 2003; Ferguson, 2005; Figuerola et al., 2005; Nawirska and Kwasniewska, 2005). Furthermore, increased consumption of DF improves serum lipid concentrations, lowers blood pressure, improves blood glucose, promotes regularity, aids in weight loss and appears to improve immune function (Anderson et al., 2009). Papadina and Bloukas (1999) state that the diet characterized through an excess of energy-dense foods, rich in fats and sugar presents a deficiency of complex carbohydrates, which constitute the major portion of dietary fiber.
Dietary fiber, as a class of compounds, includes a mixture of plant carbohydrate polymers, both oligosaccharides and polysaccharides (e.g. cellulose, hemicelluloses, pectic substances, gums, resistant starch, inulin), that may be associated with lignin, and other non-carbohydrate components (e.g. polyphenols, waxes, saponins, cutin, phytates, resistant protein) (Elleuch et al., 2011). The structural polysaccharides are the major part of plant cell walls. The types of plant material that are included within the definitions of dietary fiber may be divided into two forms, based on their water solubility: insoluble dietary fiber, which includes celluloses, some hemicelluloses and lignin; soluble dietary fiber, which include $\beta$-glucans, pectins, gums, mucilages and some hemicelluloses (Elleuch et al., 2011).

In various countries, the pumpkin flesh is processed into jams, marmalades, sweetmeats, puree for children, ready-toeat dried snacks (Gajc-Wolska et al., 2005; Gliemmo et al., 2009; Nawirska-Olszańska et al., 2011; Konopacka et al., 2010). Pumpkin can also be processed into flour, which has a longer shelf-life. This flour could be used due to its flavour, sweetness, deep yellow-orange color and considerable amount of dietary fiber. It could be use to supplement cereal flours in bakery products, soups, sauces, instant noodle and also as a natural coloring supplement for food (Noor Aziah and Komathi, 2009; Noor Aziah et al., 2011). Bread made from wheat flour supplemented by pumpkin flour had good nutritional value and sensory characteristics (See et al., 2007). With increasing the level of substitution with pumpkin flour from $5 \%$ to $15 \%$ the ash and crude fiber 
contents significantly increased. Pongjanta et al. (2006) obtained butter and chiffon cakes and cookies by adding pumpkin powder at the levels of 10, 20, 30, 40 and 50\%. The supplementation significantly increased the $\beta$-carotene content in the samples by 2.5-9.0 times.

Foods prepared from pumpkin flour could have nutritional advantage in terms of vitamins, minerals, and dietary fiber content (Noor Aziah and Komathi, 2009). Pumpkin provides valuable source of carotenoids, provitamin A and ascorbic acid, which play major roles in human nutrition and have importance as antioxidants. Current scientific researches indicate that a diet rich in foods containing $\beta$-carotene may reduce the risk of developing certain types of cancer, offers protection against heart disease and helps prevent skin diseases and vision disorders (Fraserr and Bramley, 2004; Plaza et al., 2006; Liu et al., 2009).

Fiber-rich products present on the market are primarily those of natural origin (oat, peas, maize, grain bran) which may be added to food without modifications, as well as those that must be modified before they are added (Górecka et al., 2010). Some reports state that fruit and vegetables DF concentrates have better nutritional quality than cereals, due to the presence of significant amount of bioactive compounds, such as flavonoids and carotenoids (Figuerola et al., 2005). Pumpkins are a good source of carotenoids, pectin, mineral salts, vitamins and other bioactive substances, such as phenolic compounds, so we consider that it is possible to use the pumpkin flour for enriching food with fiber. There is shortage of information about the fiber fractions in the raw material for human nutrition. Usually, they are determined only in the raw materials for feed production.

Two pumpkin species, Cucurbita maxima and Cucurbita pepo, are commonly grown in Lithuania for fruit crops and are harvested at physiological maturity. The nutritional value of pumpkin fruits is high, but varies depending on the species and cultivars. The objective of our study was to determine and compare the amount of neutral dietary fiber (NDF), acid dietary fiber (ADF), lignin and water-soluble carbohydrates (WSC) contents in pumpkin fruits flour obtained from these two species and different cultivars.

\section{Materials and methods}

The following pumpkin cultivars were selected for the investigations: Cucurbita pepo L.: 'Miranda', 'Golosemiannaja', 'Herakles', 'Danaja', 'Olga'; Cucurbita maxima Duch: 'Chutorianka', 'Zalataja grusha', 'Arina', 'Chudo judo', 'Kroshka'.

The experiment was conducted during 2010-2012 at the Experimental Station of Institute of Agriculture and Food Sciences, Aleksandras Stulginskis University. Plants were grown in the soil with the following characteristics: limnoglacial loam on moraine loam, carbonate deeper gleyic luvisol (Calearie Luvisol), slightly neutral and neutral, medium humus content, phosphorus-rich and potassiumrich. The field was not additionally fertilized with mineral or organic fertilizers. The soil was drained by drainage, the relief was artificially levelled. Sprouts of pumpkins were planted in the third decade of May, in four repetitions. The crop was harvested in the third decade of September.

\section{Flours making from pumpkin fruits}

For the production of pumpkin flours ten fruits were taken from each cultivar. The pumpkin fruits were washed halved and the seeds were removed. The pulp was peeled, sliced and dried at $60{ }^{\circ} \mathrm{C}$ in the laboratory drying oven (Termaks, Norway). Dried slices of pumpkins were grinded using the grinder (Ultra Centrifugal Mill ZM 200, Retsch, Germany) to produce flours, which were kept, chilled in an air-tight container, until the analysis. The samples were evaluated in triplicate for each analysis.

\section{Methods of samples preparation and chemical analyses}

The study reported in this paper was carried out at the chemistry laboratory of Lithuanian Research Centre of Agriculture and Forestry (LAMMC) and laboratory of food technologies, department of Horticulture, Aleksandras Stulginskis University.

Dry matter (DM) content has been determined by drying samples to the constant weight at temperature of 105 ${ }^{\circ} \mathrm{C}$ (LST EN 12145:2001). The water-soluble carbohydrates (WSC) were determined using Anthrone method (Yemm and Willis, 1954). Samples were also subjected to the fiber components analyses: acid detergent fiber (ADF) (cellulose, lignin) and acid detergent lignin $(\mathrm{ADL})$ and neutral detergent fiber (NDF) (cellulose, hemicellulose, lignin) using cell wall detergent fractionation method, according to Van Soest (Faithfull, 2002).

ADF extraction was done on an ANKOM220 Fiber Analyzer (ANKOM Technology Method 08-16-06) using F57 filter bags ( $25-\mu \mathrm{m}$ porosity). NDF was analyzed with sodium sulphite and the results were presented as ash-free. The content of cell wall structural carbohydrates hemicellulose and cellulose was calculated as it follows: cellulose $=\mathrm{ADF}-\mathrm{ADL}$ and hemicellulose $=\mathrm{NDF}-\mathrm{ADF}$ (Hindrichsen et al., 2006).

The experimental data were statistically processed by the dispersion analysis method (ANOVA), software STATISTIKA 7.0 (StatSoft, USA). Dispersion analysis was applied to evaluate chemical composition of pumpkin fruit. Arithmetical means and standard errors of the experimental data were calculated. Tukey test $(\mathrm{p}<0.05)$ was applied to estimate statistical significance of differences.

\section{Results and discussion}

Dry matter content in fruits influences yield quality. This content depends on the cultivar characteristics and climatic conditions (Tarek et al., 2001, Nawirska et al., 2008). The results showed that dry matter content in $C$. maxima fruits was higher than in $C$.pepo fruits, the quantity was twice as high (Fig. 1).

Within $C$. pepo fruits, significantly more dry matter was found in 'Golosemiannaja' and 'Danaja' flesh, while within C. maxima fruits the highest level was observed in 'Arina', 'Zalataja grusha' and 'Kroshka' cultivars. A considerable low amount of dry matter was determined in the fruits of $C$. pepo 'Olga' and C. maxima 'Chutorianka'.

There are many references to DF and DF-related problems in literature, but there is shortage of information on the DF content in the raw material, which can be used 
21

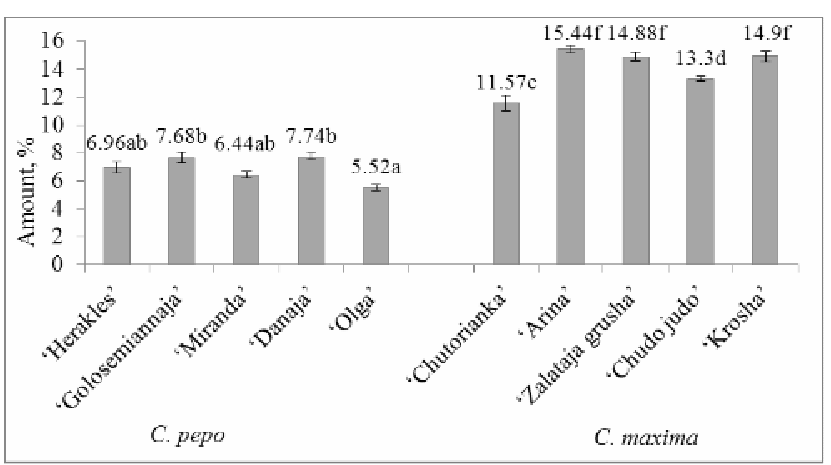

Fig. 1. Dry matter content in C. maxima and C. pepo pumpkin fruit flours; the same letters show no significant differences between means $(\mathrm{p}<0.05)$

for the production of high-fiber content preparations (Borycka and Górecka, 2001; Nawirska et al., 2008).

According to Nawirska (2008), the NDF fiber content in C. pepo fruits flesh ranges from $0.23 \%$ to $4.37 \% \mathrm{FW}$, in $C$. maxima fruits from- $1.20 \%$ to $4.37 \% \mathrm{FW}, \mathrm{ADF}$ fiber- from $0.22 \%$ to $0.47 \% \mathrm{FW}$ and $0.43-1.46 \% \mathrm{FW}$, respectively. $C$. maxima fruits accumulated higher amounts of starch, pectin, hemicellulose and NDF fiber than $C$. реро fruits. The amounts of other fiber fractions (lignin, ADF fiber.) in fruits of both species of pumpkin were similar (Nawirska et al., 2008).

Our investigations of pumpkin fruits flours revealed that the content of $\mathrm{ADF}$ ranged between $10.12 \%$ and $24.65 \%$ DM. The largest amount of ADF was found in flour obtained from 'Kroshka', while the smallest amount in flour from 'Zalataja grusha' (Tab. 1).

According to the analysis of our data it can be concluded that the NDF fiber content is more dependent on the cultivar than on the specie. The NDF content ranged between $15.5 \%$ and $26.5 \% \mathrm{DM}$ in the flour of ten pumpkin cultivars (Tab. 1). The NDF content is very high in the flour obtained from 'Kroshka' and 'Herakles' cultivars, slightly lower - in 'Chutorianka' and 'Miranda'.

The ADL content in the flour of all pumpkin cultivars was different. The ADL content varied between $0.86 \%$ and 14.3\% DM depending on cultivar (Tab. 1). The highest ADL content was determined in 'Kroshka' flour and the lowest content in - 'Zalataja grusha' and 'Arina' flour.

It was observed that flour made of 'Kroshka' contained the highest amount of water-insoluble fiber. However, in 'Herakles', 'Olga' and 'Chudo judo' fruits had the highest number of NDF and ADF fiber was found, but less of lignin ADL, which decomposes more difficultly.

A big amount of lignin is an undesirable component in NDF fiber, since it reduces other fibers, hemicellulose and cellulose, degradation (Saha, 2003). In the tested pumpkin flour a moderate correlation between ADL and NDF fractions was established $(r=0.490, p<0.05)$. It might be thought that lower lignin content in pumpkin flour would make it easier for the human organism to absorb the cellulose and hemicellulose. The strong correlation between $\mathrm{ADL}$ and ADF fractions was established $(r=0.972$, $\mathrm{p}<0.05)$. Lignin is more closely related to cellulose than to hemicellulose and has greater effect on its digestion (Van Soest at al., 1991).

Water soluble components (WSC) are quickly digested energy-rich compounds and are the primary products of photosynthesis, so their content is highly dependent on temperature, sunlight and other environmental factors (Halling et al., 2004).

The content of WSC varied, depending on cultivar. Pumpkin flours showed high content of total WSC (65.85\% DM in 'Danaja'). The lowest content of WSC was characteristic to 'Kroshka' (26.45\% DM).

\section{Conclusions}

The results imply that flour obtained from pumpkin fruits could be recommended as the component suitable for

Tab. 1. Fractional composition (mean \pm s.d.) of dietary fiber in C. maxima and C.pepo pumpkin fruit flours samples

\begin{tabular}{|c|c|c|c|c|}
\hline \multirow{2}{*}{ Cultivars } & \multicolumn{4}{|c|}{ Amount* (\% DM) } \\
\hline & NDF & ADF & $\mathrm{ADL}$ & WSC \\
\hline \multicolumn{5}{|c|}{ C. maxima } \\
\hline 'Chutorianka' & $15.50 \pm 0.14^{\mathrm{b} * *}$ & $13.55 \pm 0.07^{c}$ & $2.91 \pm 0.14^{\mathrm{ab}}$ & $61.20 \pm 0.00^{\mathrm{a}}$ \\
\hline 'Zalataja grusha' & $24.30 \pm 0.42^{c}$ & $10.12 \pm 0.39^{\mathrm{a}}$ & $0.86 \pm 0.12^{a}$ & $39.50 \pm 0.28^{b c}$ \\
\hline 'Arina' & $19.10 \pm 0.00^{\mathrm{a}}$ & $11.50 \pm 0.28^{\mathrm{ab}}$ & $1.31 \pm 0.04^{\mathrm{a}}$ & $40.45 \pm 0.64^{c}$ \\
\hline 'Chudo judo' & $25.00 \pm 0.28^{c}$ & $21.95 \pm 0.07^{c}$ & $11.80 \pm 0.42^{\mathrm{e}}$ & $38.30 \pm 0.14^{b}$ \\
\hline 'Kroshka' & $26.50 \pm 0.00^{e}$ & $24.65 \pm 1.06^{f}$ & $14.35 \pm 0.21^{\mathrm{f}}$ & $26.45 \pm 0.49^{\mathrm{e}}$ \\
\hline \multicolumn{5}{|c|}{ C. реро } \\
\hline 'Herakles' & $26.50 \pm 0.42^{\mathrm{e}}$ & $23.50 \pm 0.28^{\mathrm{ef}}$ & $12.25 \pm 0.64^{\mathrm{e}}$ & $51.05 \pm 0.49^{f}$ \\
\hline 'Golosemiannaja' & $19.10 \pm 0.56^{a}$ & $16.00 \pm 0.56^{\mathrm{g}}$ & $5.66 \pm 0.91^{c}$ & $60.85 \pm 0.07^{\mathrm{ad}}$ \\
\hline 'Miranda' & $16.40 \pm 0.00^{\mathrm{b}}$ & $12.60 \pm 0.14^{b c}$ & $4.29 \pm 0.95^{b c}$ & $62.50 \pm 0.00^{\mathrm{a}}$ \\
\hline 'Danaja' & $18.90 \pm 0.14^{\mathrm{a}}$ & $18.20 \pm 0.14^{\mathrm{d}}$ & $8.45 \pm 0.42^{\mathrm{d}}$ & $65.85 \pm 0.49^{g}$ \\
\hline 'Olga' & $21.80 \pm 0.42^{\mathrm{d}}$ & $19.35 \pm 0.07^{\mathrm{d}}$ & $7.84 \pm 0.39^{d}$ & $59.20 \pm 0.70^{d}$ \\
\hline
\end{tabular}

*Amount: NDF - neutral dietary fiber; ADF - acid dietary fiber; ADL - acid detergent lignin; WSC -water-soluble carbohydrates

${ }^{* *}$ Means in column with different letters are significantly different $(\mathrm{p}<0.05)$ for the different cultivars 
food production with high content of dietary fiber (DF). The fiber content in pumpkin fruits flour depends on the cultivar. The highest insoluble fiber content (NDF, ADF, ADL) was characteristic to flour obtained from C. maxima 'Kroshka' fruits (26.50\%, 24.65\% and 14.35\% DM, respectively), so the flour of this pumpkin cultivar is the most suitable for supplementation of food with dietary fiber.

\section{Acknowledgements}

This publication is funded by European Social Fund and the Budget of the Republic of Lithuania (Project „Eureka“ E! 6855 - ECORAW "Higher functionality food products from organic vegetable raw materials").

\section{References}

AACC Report (2001). The definition of dietary fiber. Cereal Foods World 46, 3.

Anderson JW, Baird P, Davis RH Jr, Ferreri S, Knudtson M, Koraym A, Waters V, Williams CL (2009). Health benefits of dietary fiber. Nutr Rev 67(4):188-205.

Bingham SA, Day NE, Luben R, Ferrari P, Slimani N, Norat T, Clavel-Chapelon F, Kesse E, Nieters A, Boeing H, Tjønneland A, Overvad K, Martinez C, Dorronsoro M, Gonzalez CA, Key TJ, Trichopoulou A, Naska A, Vineis P, Tumino R, Krogh V, Bueno-de-Mesquita HB, Peeters PH, Berglund G, Hallmans G, Lund E, Skeie G, Kaaks R, Riboli E (2003). Dietary fiber in food and protection against colorectal cancer in the European Prospective Investigation into Cancer and Nutrition (EPIC): an observational study. The Lancet 361(5):1496-1501.

Borderías AJ, Sánchez-Alonsa I, Pérez-Mateos M (2005). New applications of fibres in foods: Addition to fishery products. Trends Food Sci Technol 16:458-465.

Borycka B, Górecka D (2001). Charakterystyka włókna pokarmowego porzeczkowych preparatów błonnikowych [Characterization of dietary fiber in the preparation of currant pomace]. Przem Ferm Owoc-Warz 2:30-32 [in Polish].

Corréa Lima MP, Gomes-da-Silva MHG (2005). Colorectal cancer: lifestyle and dietary factors. Nutr Hosp 20:235-241.

De Almada Costa GE, da Silva Queiroz-Monici K (2006). Chemical composition, dietary fiber and resistant starch contents of raw and cooked pea, common bean, chickpea and lentil legumes. Food Chem 94:327-330.

Dolreans M, Mandran N, Sauvant D (1995). Study the use of a protease with the van Soest procedure. Anim Feed Sci Technol 61:129-136.

El-Aldawy TA, Taha KM (2001). Characteristics and composition of different seeds oils and flours. Food Chem 74:47-54.

Elleucha M, Bedigian D, Roiseux O, Besbes S, Blecker Ch, Attia H (2011). Dietary fibre and fibre-rich by-products of food processing: Characterisation, technological functionality and commercial applications: A review. Food Chem 124:411-421.
Faithfull NT (2002). Methods in agricultural chemical analysis: a practical handbook. Wallingford, USA. 266 p.

Ferguson LR, Harris PJ (2003). The dietary fibre debate: more food for thought. The Lancet 361:1487-1488.

Ferguson LR (2005). Does a diet rich in dietary fibre really reduce risk of colon cancer? Digest Liver Dis 37:139-141.

Figuerola F, Hurtado ML, Estévaz AM, Chiffelle I, Asenjo F (2005). Fiber concentrates from apple pomace and citrus peel as potential fibre sources for food enrichment. Food Chem 91:395-401.

Fraser PD, Bramley PM (2004). The biosynthesis and nutritional uses of carotenoids. Prog in Lip Res 43:228-265.

Gajc-Wolska J, Gajewski M, Radzanowska J, Niemirowicz-Szczytt K, Korzeniewska A (2005). The fruit quality of chosen hybrids and cultivars of pumpkin (Cucurbita maxima Duch.). Veget Crops Res Bull 63:34-43.

Gliemmo MF, Latorre ME, Gerschenson LN, Campos CA (2009). Color stability of pumpkin (Cucurbita moschata, Duchesne ex Poiret) puree during storage at room temperature: Effect of $\mathrm{pH}$, potassium sorbate, ascorbic acid and packaging material. Food Sci Technol 42:196-201.

Górecka D, Pachołek B, Dziedzic K, Górecka M (2010). Raspberry pomace as a potential fiber source for cookies enrichment. Acta Scientiarum Polonorum Technol Aliment $9(4): 451-462$.

Grigelmo-Miguel N, Martín-Belloso O (1999). Comparison of dietary fiber from by-products of processing fruits and greens and from cereals. Lebensm Wiss Technol 32:503-508.

Halling MA, Longland AC, Martens S, Nesheim L, O'Kiely P (2004). Accumulation of water soluble carbohydrates in two perennial ryegrass cultivars at nine European sites. Grassland Science in Europe 9:954-956.

Hindrichsen IK, Kreuzer M, Madsen J, Knudsen KEB (2006). Fiber and lignin analysis in concentrate, forage, and feces: Detergent versus enzymatic-chemical method. J Dairy Sci 89(6):2168-2176.

Jenkins DJA, Kendall CWC, Ransom TPP (1998). Dietary fiber, the evolution of the human diet and coronary heart disease. Nutr Res 18:633-652.

Jiménez-Escrig A, Sánchez-Muni FJ (2000). Dietary fiber from Edible seaweeds: chemical structure, physicochemical properties and effects on cholesterol metabolism. Nutr Res 20:585-598.

Konopacka D, Seroczyńska A, Korzeniewska A, Jesionkowsk K, Niemirowicz-Szczytt K, Plocharski W (2010). Studies on the usefulness of Cucurbita maxima for the production of readyto-eat dried vegetable snacks with a high carotenoid content. Food Sci Technology 43(2):302-309.

Liu GN, Zhu YH, Jiang JG. (2009). The metabolomics of carotenoids in engineered cell factory. Appl Microbiol Biotechnol 83(6):989-999.

LST EN 12145:2001 (2001). Fruit and vegetable juices Determination of total dry matter - Gravimetric method with 
loss of mass on drying.

Mai V, Flood A, Peters U, Lacey JV Jr, Schairer C, Schatzkin A (2003). Dietary fiber and risk of colorectal cancer in the Breast Cancer Detection Demonstration Project (BCDDP) followup cohort. Int J Epidemiol 32:234-239.

Nawirska A (2005). Binding of metal ions by selected fractions of fruit pomace. Food Chem 90:395-400.

Nawirska A, Kwasniewska M (2005). Dietary fiber fractions from fruit and vegetable processing waste. Food Chem 91:221-225.

Nawirska A, Sokół-Łętowska A, Kucharska AZ, Biesiada A, Bednarek M (2008). Porównanie zawartośći frakcji włókna pokarmowego w dmianach dyni z gatunku Cucurbita maxima i Cucurbita pepo (Comparing the contents of dietary fibre fractions in some varieties of Cucurbita maxima and Cucurbita pepo). Żywność Nauka Technologia Jakość 1(56):65-73 [in Polish].

Nawirska-Olszańska A, Biesiada A, Sokół-Łętowska A, Kucharsk AZ (2011). Content of bioactive compounds and antioxidant capacity of pumpkin puree enriched with japanese quince, cornelian Cherry, strawberry and apples. Acta Scientiarum Polonorum Technol Aliment 10(1):51-60.

Noor Aziah AA, Komathi CA (2009). Physicochemical and Functional Properties of Peeled and Unpeeled Pumpkin Flour. J Food Sci 74(7):328-333.

Noor Aziah AA, Komathi CA, Bhat R (2011). Evaluation of Resistant Starch in Creckers Incorporated with Unpeeld and Peeled Pumpkin Flour. Am J Food Technol 6(12):1054-1060.

Papadina SN, Bloukas JG (1999). Effect of fat level and storage conditions on quality characteristics of traditional Greek sausages. Meat Sci 51:103-113.

Plaza L, Sanchez-Moreno C, Elez-Martınez P, De Ancos B, Martın-Belloso O, Pilar Cano M (2006). Effect of refrigerated storage on vitamin $\mathrm{C}$ and antioxidant activity of orange juice processed by high-pressure or pulsed electric fields with regard to low pasteurization. Eur Food Res Technol 223:487-493.
Pongjanta J, Naulbunrang A, Kawngdang S, Manon T, Thepjaikat $\mathrm{T}$ (2006). Utilization of pumpkin powder in bakery products. J Sci Technol 28(1):71-9.

Prosky L (1999). What is fibre? Current controversies. Trends Food Sci Technol 10: 271-275.

Rahman ZU, Islam M, Shah WH (2002). Effect of microwave and conventional cooking on insoluble dietary fibre components of vegetables. Food Chem 80:237-240.

Rodrígez R, Jimenez A, Fernández-Bolaños J, Guillén R, Heredia A (2006). Dietary fibre from vegetable products as source of functional ingredients. Trends Food Sci Technol 17:3-15.

Saha BC (2003). Hemicelluloze bioconversion. J Ind Microbiol Biotechnol 30:279-291.

Sangnark A, Noomhorm A (2003). Effect of particle sizes on invitro calcium and magnesium binding capacity of prepared dietary fibers. Food Res Int 36:91-96.

See EF, Wan Nadiah WA, Noor Aziah AA (2007). PhysicoChemical and Sensory Evaluation of Breads Supplemented with Pumpkin Flour. ASEAN Food Journal 14(2):123-130.

Van Soest PJ, Robertson JB, Lewis BA (1991). Symposium: Carbohydrate methodology, metabolism, and nutritional implications in dairy cattle. J Dairy Sci 74:3583-3597.

Wang J, Rosell CM, de Barber CB (2002). Effect of the addition of different fibres on wheat dough performance and bread quality. Food Chem 79:221-226.

Yemm EW, Willis AJ (1954). The estimation of carbohydrates in plant extracts by Anthrone. Biochem J 57:508-514. 